\title{
Effect of Diet on Replacement Beef Heifer Growth and Reproductive Performance
}

\author{
Janice G. P. Bowman (Corresponding author) \\ Dept. of Animal \& Range Sciences, Montana State University, \\ United States. E-mail: jbowman@montana.edu
}

Bok F. Sowell

Dept. of Animal \& Range Sciences, Montana State University

United States. E-mail: bok@montana.edu

Received: August 3, 2017

doi:10.5296/jas.v5i3.11635
Accepted: August 17, 2017 Published: September 5, 2017

URL: https://doi.org/10.5296/jas.v5i3.11635

\begin{abstract}
One hundred-one crossbred beef heifers (average weight $256.1 \mathrm{~kg}$ ) were used to evaluate the effects of diet during an 84-day period, on growth and reproductive performance. The four treatments were: 1) grass hay; 2) grass hay $+0.9 \mathrm{~kg} /$ day barley; 3) grass hay $+1.8 \mathrm{~kg} / \mathrm{day}$ barley; and 4) alfalfa hay. Heifers were assigned randomly to 12 pens by weight (three pens/treatment). Prior to feeding, barley was cracked through a roller-mill. Heifers consuming alfalfa hay or grass hay $+1.8 \mathrm{~kg}$ barley gained $39 \%$ faster $(0.68$ and $0.74 \mathrm{~kg} / \mathrm{day}$, respectively; $\mathrm{P}=0.01)$ than heifers consuming grass hay alone $(0.51 \mathrm{~kg} / \mathrm{day})$. Heifers consuming grass hay $+0.9 \mathrm{~kg}$ barley were intermediate in average daily gain (ADG; 0.63 $\mathrm{kg}$ /day). Hay intake was $16 \%$ greater $(\mathrm{P}<0.10)$ by heifers consuming alfalfa hay, grass hay, and grass hay $+0.9 \mathrm{~kg}$ barley compared with those consuming grass hay $+1.8 \mathrm{~kg}$ barley (average $8.1 \mathrm{vs} 7.0 \mathrm{~kg} / \mathrm{day}$ ). Using costs (USD) of $\$ 0.066 / \mathrm{kg}$, $\$ 0.099 / \mathrm{kg}$, and $\$ 0.0935 / \mathrm{kg}$ for grass hay, alfalfa hay, and barley, respectively, feed cost/day was greatest $(\mathrm{P}<0.01)$ for alfalfa hay (\$0.81/day), intermediate for the grass hay + barley diets (average \$0.63/day), and lowest for grass hay $(\$ 0.53 /$ day $)$. Cost $/ \mathrm{kg}$ gain was less $(\mathrm{P}<0.10)$ for grass hay $+1.8 \mathrm{~kg}$ barley compared with alfalfa hay. No diet differences $(\mathrm{P}>0.70)$ were found in reproductive performance of the heifers. Feeding replacement heifers alfalfa hay resulted in performance equivalent to feeding grass hay $+1.8 \mathrm{~kg}$ barley, but the alfalfa hay diet had a higher cost.
\end{abstract}


Keywords: alfalfa hay, grass hay, barley, replacement heifers, growth, reproductive performance

\section{Introduction}

In beef cow/calf systems, a major cost is the need for development or purchase of replacement heifers (Hess, 2003). For beef cows, one of the most important traits determining longevity and efficiency of reproduction, is the age at puberty (Schillo et al., 1992). The most significant characteristic impacting a heifer's age at puberty is her nutritional condition and her subsequent growth rate and reproductive development (Patterson et al., 1992). Therefore, nutritional management of replacement heifers is of great importance to the continued development of the cattle herd. The target of having beef heifers weigh $2 / 3$ of their mature body weight at one year of age, generally accepted as the point of puberty, must also be attained at a cost-effective rate.

Barley feeding occurs primarily in areas where it is extensively grown and relatively inexpensive compared with corn and other cereal grains (Neumann \& Lusby, 1986). Barley is one of the feedstuffs most frequently used as the primary energy source for feedlot cattle throughout the Northwest United States (Poehlman, 1985; Hunt, 1996; Zhao et al., 2016). The state of Montana is a major producer of both barley and replacement beef heifers. Utilization of barley in heifer development programs is of interest to both barley growers and beef producers of the region.

In this study, our objectives were to test the relationship between diets based on alfalfa hay only, grass hay only, grass hay $+0.9 \mathrm{~kg} /$ day barley, and grass hay $+1.8 \mathrm{~kg} /$ day barley and beef replacement heifer growth and reproductive performance.

\section{Materials and Methods}

\subsection{Animals and Feeding Management}

All animal procedures were conducted in accordance with regulations approved by the Montana State University Agricultural Animal Care and Use Committee.

This experiment was conducted at the Montana State University Bozeman Agricultural Research and Teaching farm. One hundred-one Angus x Hereford crossbred beef heifer calves (average initial weight $256.1 \mathrm{~kg}$ ) were assigned by weight to one of 12 pens in a completely randomized design with three pens per treatment. All heifers were treated with anthelmintics 2 months prior to the experiment. The four dietary treatments consisted of: 1) alfalfa hay only; $22.0 \%$ crude protein (CP), 36.7\% neutral detergent fiber (NDF); 2) grass hay only ( $8.4 \% \mathrm{CP}, 65.5 \% \mathrm{NDF})$; 3) grass hay $+0.9 \mathrm{~kg} /$ day barley; and 4) grass hay $+1.8 \mathrm{~kg} /$ day barley. A tub grinder with a 5-cm screen setting was used to chop both hays prior to feeding. The barley $(11.8 \% \mathrm{CP}, 13.3 \% \mathrm{NDF})$ was coarsely cracked through a hammer mill, and top dressed on the grass hay. Each pen had a trace mineralized salt block available and heifers given ad libitum access to water. Feed bunks were checked every morning at 0700. Daily rations were calculated to provide each pen with enough hay so that $5 \%$ of the hay remained in the bunks the following morning. Due to the size of the feed bunks and the amount of grass 


\section{Macrothink}

hay fed, the grass hay pens were fed twice daily (0730 and 1630). The alfalfa hay was dense enough to allow feeding once daily (0730). Grass hay was fed ad libitum, and alfalfa hay was fed at a level equal to the highest grass hay intake.

\subsection{Nutrient Composition}

Grab samples of hay and barley were collected twice a week and composited for analysis. All feed samples were dried $\left(60^{\circ} \mathrm{C}\right)$ and ground through a 1-mm screen in a Wiley mill. Two 1-g aliquots of the $1-\mathrm{mm}$ samples were weighed, dried for 24 hours at $100^{\circ} \mathrm{C}$, and then reweighed to determine dry matter (DM) content (AOAC, 2000). All feed samples were evaluated for $\mathrm{N}$ content (AOAC, 2000; LECO Corp., St. Joseph, MI), and then analyzed for NDF (Van Soest et al., 1991).

\subsection{Performance Measures}

The experiment began December 31, and heifers were weighed at the beginning and end of the 84-day feeding experiment on 2 consecutive days, with the consecutive weights averaged. Average daily gain, average daily forage intake, and feed efficiency were calculated. Feed cost per day and feed cost $/ \mathrm{kg}$ gain were calculated using costs of $\$ 0.066 / \mathrm{kg}, \$ 0.099 / \mathrm{kg}$, and $\$ 0.0935 / \mathrm{kg}$ for grass hay, alfalfa hay, and barley, respectively.

Heifers were synchronized for artificial insemination breeding (April 30 to May 2). Heifers detected in heat were bred during this interval by a trained AI technician 12 hours after the beginning of estrus. Subsequently they were grouped together with clean-up bulls, and fed grass/alfalfa hay. At calving the following spring, calf birth date and success were recorded.

\subsection{Statistical Analyses}

The Proc GLM procedure (SAS Inst., Inc., Cary, NC) was used to analyze the data as a completely randomized design. The experimental unit for all data was the pen $(n=12)$. The Least Significant Difference procedure was used to separate the means when a significant $F$ value was found $(\mathrm{P} \leq 0.10)$. Proc FREQ of SAS was used to analyze the pregnancy data with $\chi^{2}$.

\section{Results and Discussion}

\subsection{Performance Measures}

Heifer initial weight, average daily gain, total gain, hay intake, feed efficiency, and feed costs are presented in Table 1. 
Table 1. Performance, forage intake, and feed costs for replacement heifers fed alfalfa hay alone, grass hay alone, grass hay $+0.9 \mathrm{~kg}$ barley, or grass hay $+1.8 \mathrm{~kg}$ barley during an 84 -day feeding period.

\begin{tabular}{|c|c|c|c|c|c|c|}
\hline Item & Alfalfa hay & Grass hay & $\begin{array}{l}\text { Grass hay }+ \\
0.9 \mathrm{~kg} \text { barley }\end{array}$ & $\begin{array}{l}\text { Grass hay }+ \\
1.8 \mathrm{~kg} \text { barley }\end{array}$ & SEM & P-value \\
\hline No. of heifers & 26 & 26 & 24 & 25 & --- & --- \\
\hline $\begin{array}{l}\text { Initial weight, } \\
\mathrm{kg}\end{array}$ & 256.1 & 256.4 & 256.6 & 257.3 & 0.98 & 0.84 \\
\hline $\begin{array}{l}\text { 84-day ADG, } \\
\text { kg/day }\end{array}$ & $0.68^{\mathrm{b}}$ & $0.51^{\mathrm{a}}$ & $0.63^{\mathrm{ab}}$ & $0.74^{\mathrm{b}}$ & 0.062 & 0.01 \\
\hline Gain, kg & $57.3^{\mathrm{b}}$ & $43.2^{\mathrm{a}}$ & $52.7^{\mathrm{ab}}$ & $62.6^{\mathrm{b}}$ & 5.21 & 0.01 \\
\hline $\begin{array}{l}\text { Final weight, } \\
\mathrm{kg}\end{array}$ & $313.4^{\mathrm{b}}$ & $299.7^{\mathrm{a}}$ & $309.4^{\mathrm{ab}}$ & $319.9^{b}$ & 4.89 & 0.08 \\
\hline $\begin{array}{l}\text { Hay intake, } \\
\mathrm{kg} / \text { day }\end{array}$ & $8.2^{\mathrm{b}}$ & $8.1^{b}$ & $8.1^{b}$ & $7.0^{\mathrm{a}}$ & 0.30 & 0.07 \\
\hline $\begin{array}{l}\text { Feed } \\
\text { efficiency, } \\
\text { (feed/gain) }\end{array}$ & $12.2^{\mathrm{ab}}$ & $15.7^{\mathrm{b}}$ & $13.7^{\mathrm{b}}$ & $9.5^{\mathrm{a}}$ & 1.52 & 0.09 \\
\hline $\begin{array}{l}\text { Feed costs, } \\
\$ / \text { day }\end{array}$ & $0.81^{\mathrm{c}}$ & $0.53^{\mathrm{a}}$ & $0.62^{\mathrm{b}}$ & $0.63^{\mathrm{b}}$ & 0.019 & 0.01 \\
\hline $\begin{array}{l}\text { Feed costs, } \\
\$ / \mathrm{kg} \text { gain }\end{array}$ & $1.20^{\mathrm{b}}$ & $1.03^{\mathrm{ab}}$ & $1.04^{\mathrm{ab}}$ & $0.85^{\mathrm{a}}$ & 0.118 & 0.07 \\
\hline
\end{tabular}

$\overline{a, b, c}$ Means within a row with different superscripts differ $(\mathrm{P}<0.10)$.

After 84 days consuming their respective diets, heifer average daily gain, total gain, and final weight exhibited the same pattern of results. Heifers fed grass hay $+1.8 \mathrm{~kg}$ barley or alfalfa hay alone gained on average, $16.8 \mathrm{~kg}$ more than heifers fed grass hay alone. Heifers fed grass hay $+0.9 \mathrm{~kg}$ barley gained an amount intermediate to those fed the three other diets.

Hay intake was lowest for heifers fed grass hay $+1.8 \mathrm{~kg}$ barley $(7 \mathrm{~kg} / \mathrm{day})$, and averaged 8.1 $\mathrm{kg} /$ day for heifers fed alfalfa hay alone, grass hay alone, and grass hay $+0.9 \mathrm{~kg}$ barley. This may be due to the negative effects starch can have on fiber digestion in the rumen. Cereal grains and other high starch feeds have resulted in decreased intake and digestibility of low-quality forages (Tamminga, 1993; Bowman et al., 2004). Starch has been shown to have a negative effect on fiber digestion (Firkins et al., 1991; Russell and Wilson, 1996). This depression in structural carbohydrate digestion may be an outcome of low ruminal $\mathrm{pH}$ from increased volatile fatty acid content on the growth of fibrolytic organisms (Hiltner and Dehority, 1983; Tamminga and Van Vuuren, 1988), from increased structural carbohydrate 
digestion lag time due to preferred use of nonstructural carbohydrates by fibrolytic organisms (Mertens and Loften, 1980; Hoover, 1986), or from fibrolytic and amylolytic organisms competing for nutrients (Hoover, 1986).

Feed efficiency was most desirable for heifers fed grass hay $+1.8 \mathrm{~kg}$ barley. Feeding heifers $1.8 \mathrm{~kg}$ of barley reduced hay intake, but provided adequate energy to maintain the highest average daily gain. Daily feed costs were least for heifers fed grass hay only (\$0.53/day), and greatest for heifers fed alfalfa hay $(\$ 0.81 /$ day). Cost per pound of gain was least for heifers fed grass hay $+1.8 \mathrm{~kg}$ barley $(\$ 0.85 / \mathrm{kg})$.

\subsection{Reproductive Performance}

Reproductive performance of the replacement heifers is presented in Table 4. There were no differences $(\mathrm{P}>0.10)$ in calves born, or number of AI calves, averaging 19 total calves, and 8 AI calves born per treatment. Calving date was not affected $(\mathrm{P}=0.89)$ by treatment.

Table 2. Reproductive performance by replacement heifers fed alfalfa hay alone, grass hay alone, grass hay $+0.9 \mathrm{~kg}$ barley, or grass hay $+1.8 \mathrm{~kg}$ barley during an 84 -day feeding period.

\begin{tabular}{|c|c|c|c|c|c|}
\hline Item & Alfalfa hay & Grass hay & $\begin{array}{l}\text { Grass hay }+ \\
0.9 \mathrm{~kg} \text { barley }\end{array}$ & $\begin{array}{l}\text { Grass hay }+ \\
1.8 \mathrm{~kg} \text { barley }\end{array}$ & P-value \\
\hline No. of heifers & 26 & 26 & 24 & 25 & --- \\
\hline $\begin{array}{l}\text { No. of calves } \\
\text { born }\end{array}$ & 20 & 21 & 16 & 19 & 0.70 \\
\hline $\begin{array}{l}\text { No. of AI } \\
\text { calves born }\end{array}$ & 8 & 9 & 7 & 7 & 0.97 \\
\hline $\begin{array}{l}\text { Average } \\
\text { calving date }\end{array}$ & Feb. 16 & Feb. 21 & Feb. 17 & Feb. 20 & 0.83 \\
\hline
\end{tabular}

\section{Conclusion}

Crossbred beef replacement heifers fed grass hay $+1.8 \mathrm{~kg}$ barley gained more weight, but had a higher daily feed cost during an 84-day feeding period than did heifers fed grass hay alone. Replacement heifers consuming alfalfa hay resulted in similar gains, but a greater cost per kilogram of gain, compared with heifers consuming grass hay $+1.8 \mathrm{~kg}$ barley. All four of the diets supported average daily gains over $0.45 \mathrm{~kg} /$ day, and resulted in similar reproductive performance by replacement heifers. Feeding replacement heifers grass hay alone $(8.4 \% \mathrm{CP})$ for 84 days, resulted in the lowest feed cost, and allowed an adequate growth rate $(0.51$ $\mathrm{kg} /$ day) for heifers to reach puberty, conceive, and calve early their first calving season.

\section{Acknowledgements}

This material is based upon work that is supported by the National Institute of Food and Agriculture, U.S. Department of Agriculture, Hatch project under 1009640 accession number. 


\section{References}

AOAC. (2000). Official Methods of Analysis. (17th ed.). Arlington, VA: Association of Official Analytical Chemists.

Bowman, J. G. P., Sowell, B. F., Surber, L. M. M., \& Daniels, T. K. (2004). Nonstructural carbohydrate supplementation of yearling heifers and range beef cows. Journal of Animal Science, 82, 2724-2733. http://dx.doi.org/10.2527/2004.8292724x

Firkins, J. L., Bowman, J. G. P., Weiss, W. P., \& Naderer, J. (1991). Effects of protein, carbohydrate, and fat sources on bacterial colonization and degradation of fiber in vitro. Journal of Dairy Science, 74, 4273-4283. http://doi.org/10.3168/jds.S0022-0302(91)78622-0

Hess, B. W. (2003). Supplementing fat to the cow herd. In Proceedings of the XVIII Range Beef Cow Symposium, 156-165. Scottsbluff, NE: Mitchell Nebraska Printworks.

Hiltner, P., \& Dehority, B. A. (1983). Effect of soluble carbohydrates on digestion of cellulose by pure cultures of rumen bacteria. Applied Environmental Microbiology, 46, 642-648.

Hoover, W. H. (1986). Chemical factors involved in ruminal fiber digestion. Journal of Dairy Science, 60, 2755-2766. https://doi.org/10.3168/jds.S0022-0302(86)80724-X

Hunt, C. W. (1996). Factors affecting the feeding quality of barley for ruminants. Animal Feed Science and Technology, 62, 37-48. http://doi.org/10.1016/S0377-8401(96)01004-8

Mertens, D. R., \& Loften, J. R. (1980). The effect of starch on forage fiber digestion kinetics in vitro. Journal of Dairy Science, 63, 1437-1446.

https://doi.org/10.3168/jds.S0022-0302(80)83101-8

Neumann, A. L., \& Lusby, K. S. (1986). Beef Cattle (8th ed.). New York, NY: John Wiley \& Sons, 212-228.

Patterson, D. J., Perry, R. C., Kiracofe, G. H., Bellows, R. A., Staigmiller, R. B., \& Corah, L. R. (1992). Management considerations in heifer development and puberty. Journal of Animal Science, 70, 4018-4035. http://dx.doi.org/10.2527/1992.70124018x

Poehlman, J. M. (1985). Adaption and distribution. In D. Rasmusson (Ed.), Barley: Agronomy Monograph, 26. Madison, WI: ASA-CSSA-SSSA.

Russell, J. B., \& Wilson, D. V. (1996). Why are ruminal cellulolytic bacteria unable to digest cellulose at low pH? Journal of Dairy Science, 79, 1503-1509.

https://doi.org/10.3168/jds.S0022-0302(96)76510-4

Schillo, K. K., Hall, J. B., \& Hileman, S. M. (1992). Effects of nutrition and season on the onset of puberty in the beef heifer. Journal of Animal Science, 70, 3994-4005.

http://dx.doi.org/10.2527/1992.70123994x

Tamminga, S. (1993). Influence of feeding management on ruminant fiber digestibility. In H. G. Jung, D. R. Buxton, R. D. Hatfield, \& J. Ralph (Eds.), Forage Cell Wall Structure and Digestibility, 571-602. Madison, WI: Am. Soc. Agron. 


\section{Macrothink}

Journal of Agricultural Studies

ISSN 2166-0379 2017, Vol. 5, No. 3

Tamminga, S., \& Van Vuuren, A. M. (1988). Formation and utilization of end products of lignocellulose degradation in ruminants. Animal Feed Science and Technology, 21, 141-159. https://doi.org/10.1016/0377-8401(88)90096-X

Van Soest, P. J., Robertson, J. B., \& Lewis, B. A. (1991). Methods for dietary fibre, neutral detergent fibre and non starch polysaccharide in relation to animal nutrition. Journal of Dairy Science, 74, 3538-3597. http://doi.org/10.3168/jds.S0022-0302(91)78551-2

Zhao, Y., Yan, S., He, Z., Anele, U. Y., Swift, M. L., McAllister, T. A., \& Yang, W. (2016). Effect of starch content and processing method on in situ ruminal and in vitro intestinal digestion of barley grain in beef heifers. Animal Feed Science and Technology, 216, 121-128. https://doi.org/10.1016/j.anifeedsci.2016.03.025

\section{Copyright Disclaimer}

Copyright for this article is retained by the author(s), with first publication rights granted to the journal.

This is an open-access article distributed under the terms and conditions of the Creative Commons Attribution license (http://creativecommons.org/licenses/by/4.0/). 